\title{
Behavior of mercury in a soil-plant system as affected by inoculation with the arbuscular mycorrhizal fungus Glomus mosseae
}

\author{
Yang Yu $\cdot$ Shuzhen Zhang $\cdot$ Honglin Huang
}

Received: 2 September 2009 /Accepted: 14 December 2009 /Published online: 14 January 2010

(C) Springer-Verlag 2010

\begin{abstract}
Effects of inoculation with the arbuscular mycorrhizal (AM) fungus Glomus mosseae on the behavior of $\mathrm{Hg}$ in soil-plant system were investigated using an artificially contaminated soil at the concentrations of 0 , $1.0,2.0$, and $4.0 \mathrm{mg} \mathrm{Hg} \mathrm{kg}{ }^{-1}$. Mercury accumulation was lower in mycorrhizal roots than in nonmycorrhizal roots when $\mathrm{Hg}$ was added at the rates of 2.0 and $4.0 \mathrm{mg} \mathrm{kg}^{-1}$, while no obvious difference in shoot $\mathrm{Hg}$ concentration was found between mycorrhizal and nonmycorrhizal treatments. Mycorrhizal inoculation significantly decreased the total and extractable $\mathrm{Hg}$ concentrations in soil as well as the ratio of extractable to total $\mathrm{Hg}$ in soil. Equilibration sorption of $\mathrm{Hg}$ by soil was investigated, and the results indicated that mycorrhizal treatment enhanced $\mathrm{Hg}$ sorption on soil. The uptake of $\mathrm{Hg}$ was lower by mycorrhizal roots than by nonmycorrhizal roots. These experiments provide further evidence for the role of mycorrhizal inoculation in increasing immobilization of $\mathrm{Hg}$ in soil and reducing the uptake of $\mathrm{Hg}$ by roots. Calculation on mass balance of $\mathrm{Hg}$ in soil suggests the presence of $\mathrm{Hg}$ loss from soil presumably through evaporation, and AM inoculation enhanced $\mathrm{Hg}$ evaporation. This was evidenced by a chamber study to detect the $\mathrm{Hg}$ evaporated from soil.
\end{abstract}

Keywords Arbuscular mycorrhizal fungus · Mercury · Soil · Uptake $\cdot$ Maize

Y. Yu $\cdot$ S. Zhang $(\bowtie) \cdot H$. Huang

State Key Laboratory of Environmental Chemistry and Ecotoxicology,

Research Center for Eco-Environmental Sciences, Chinese Academy of Sciences,

P.O. Box 2871, Beijing 100085, China

e-mail: szzhang@rcees.ac.cn

\section{Introduction}

$\mathrm{Hg}$, a worldwide hazard, is increasingly released to the environment by anthropogenic activities such as coal burning and mining (Han et al. 2002). Mercury in soil can enter and accumulate in the food chain through plant uptake, posing a potential danger to human health and welfare (Gnamuš et al. 2000). Therefore, understanding the behavior and fate of $\mathrm{Hg}$ in soil-plant system is very important to assess its environmental risk.

Mercury in soil can be taken up by plants, and bioavailability of $\mathrm{Hg}$ in soil is to a large extent determined by its interactions with soil. Most of $\mathrm{Hg}$ in soil is either bound to minerals or adsorbed onto solid inorganic and organic surfaces, and only a small part of $\mathrm{Hg}$ in soil (e.g., water soluble and exchangeable fractions) is considered to be bioavailable to plants (Schuster 1991; Millán et al. 2006). Mercury sorption/desorption on soil is subjected to a wide array of chemical and biological transformation processes such as oxidation/reduction, methylation, and complexation. Therefore, it depends on a complex of factors including soil properties such as soil $\mathrm{pH}$, texture and organic matter, soil temperature, and complex ligands (e.g., $\mathrm{OH}^{-}$and $\mathrm{Cl}^{-}$) in soil (Schuster 1991). Soil organic matter exhibits a great affinity for $\mathrm{Hg}$; therefore, its content and composition would have a significant influence on $\mathrm{Hg}$ sorption/desorption behavior in soil (Yin et al. 1997; Grigal 2003). In addition, $\mathrm{Hg}$ in soil can evaporate into air as the forms of either organic $\mathrm{Hg}$ or elemental mercury $(\mathrm{Hg}(0))$. Transformation of divalent inorganic $\mathrm{Hg}$ ( $\mathrm{Hg}(\mathrm{II}))$ to organic $\mathrm{Hg}$ and/or $\mathrm{Hg}(0)$ occurring in the uppermost soil layers is the rate-limiting process of $\mathrm{Hg}$ evaporation (Schlüter 2000). Several abiotic and biotic factors contribute to the conversion of $\mathrm{Hg}$ species in soil. Soil organic matter, in particular dissolved organic matter, has been demonstrated to mediate 
the nonbiological process and affect $\mathrm{Hg}$ speciation (Schlüter 2000), while soil microbe is considered to play a key role in the biological process of $\mathrm{Hg}$ reduction and methylation in soil (Gabriel and Williamson 2004).

Arbuscular mycorrhizal (AM) fungi are ubiquitous in soil, forming symbiotic associations with roots of the majority of plant species (Smith and Read 1997). It has been addressed that mycorrhizal inoculation can affect the accumulation of metals such as $\mathrm{Cu}, \mathrm{Cd}, \mathrm{Zn}$, and $\mathrm{As}$ by plants and enhance the tolerance of host plants to contamination of these metals in soil (González-Chávez et al. 2002; Janoušková et al. 2006; Marques et al. 2006; Yu et al. 2009). However, the interaction between AM fungi and $\mathrm{Hg}$ in soil-plant system has not been studied so far. AM inoculation can influence soil properties and soil microbial community (Smith and Read 1997; Li and Christie 2001). Qualitative changes in root exudation and rhizodeposition following AM colonization have also been reported (Jones et al. 2004). All of these are speculated to change the speciation, mobility, and bioavailability of $\mathrm{Hg}$ in soil, therefore influencing its behavior in soil-plant system.

The aim of the present study was to investigate the behavior of $\mathrm{Hg}$ in soil-plant system as affected by inoculation with AM fungus. Maize was used as the model plant and the soil was spiked with $\mathrm{Hg}$ at different concentrations. The uptake of $\mathrm{Hg}$ by roots and sorption of $\mathrm{Hg}$ on soil were characterized and compared between mycorrhizal and nonmycorrhizal treatments in order to understand the contribution of AM inoculation to the uptake of $\mathrm{Hg}$ by plants and the immobilization of $\mathrm{Hg}$ in soil. A chamber study was carried out to monitor the evaporation of $\mathrm{Hg}$ from soil for mycorrhizal and nonmycorrhizal treatments.

\section{Materials and methods}

Inoculum and soil preparation

Inoculum of the AM fungus (Glomus mosseae, BGC XJ01), isolated from a noncontaminated soil in Sinkiang, China, was propagated for 10 weeks in pot culture on broomcorn (Sorghum vulgare Pers.) plants grown in a soilsand media in a greenhouse. The inoculum, which was airdried and sieved $(<2 \mathrm{~mm})$, consisted of spores, mycelium, sandy soil, and root fragments and had approximately 180 propagules per gram of dry soil based on the most probable number estimation (Porter 1979).

A sandy soil (Alfisol) collected from the surface horizon $(0-15 \mathrm{~cm}$ depth $)$ of a field in a farm near Beijing was airdried, ground, and passed through a 2-mm sieve. The soil has the following properties (on a dry weight soil basis): $\mathrm{pH}$ (1:2.5 soil to water), 8.3 ; organic matter, $0.39 \%$; cation exchange capacity, $65.8 \mathrm{cmol} \mathrm{kg}^{-1}$; total $\mathrm{Hg}, 0.04 \mathrm{mg} \mathrm{kg}^{-1}$; and $0.5 \mathrm{~mol} \mathrm{~L}^{-1} \mathrm{NaHCO}_{3}$-extractable $\mathrm{P}, 2.75 \mathrm{mg} \mathrm{kg}^{-1}$. The soil was sterilized by $\gamma$-irradiation $(10 \mathrm{kGy}, 10 \mathrm{MeV} \gamma$ ray) for the elimination of native AM fungi. An application of $200 \mathrm{mg} \mathrm{kg}^{-1} \mathrm{~N}\left(\mathrm{NH}_{4} \mathrm{NO}_{3}\right), 60 \mathrm{mg} \mathrm{kg}^{-1} \mathrm{P}\left(\mathrm{KH}_{2} \mathrm{PO}_{4}\right)$, and $150 \mathrm{mg} \mathrm{kg}^{-1} \mathrm{~K}\left(\mathrm{~K}_{2} \mathrm{SO}_{4}\right)$ was added in the soil as a basal fertilizer.

Plant growth and harvest

Mercury was added as $\mathrm{HgCl}_{2}$ in solution and mixed with the soil by shaking for $24 \mathrm{~h}$ to obtain the homogeneous artificially contaminated soils at the concentrations of 1.0 , 2.0 , and $4.0 \mathrm{mg} \mathrm{kg}^{-1}$, respectively. Soil without addition of $\mathrm{Hg}$ was used as blank control. The soils were equilibrated for a period of 4 weeks by undergoing four cycles of saturation with deionized water and air-dried in a greenhouse. Triplicate pots were prepared for each treatment. Pots received a mixture of $650 \mathrm{~g}$ soil and $50 \mathrm{~g}$ inoculum for mycorrhizal treatment or sterilized inoculum plus $15 \mathrm{~mL}$ of inoculum washings filtered through a $37-\mu \mathrm{m}$ filter paper for nonmycorrhizal treatment. Seeds of maize (Zea mays L. cv. ND108; from China Agricultural University, Beijing, China) were surface sterilized in a $10 \%(v / v)$ solution of hydrogen peroxide and then pregerminated on a moist filter paper for 2 days. Four pregerminated maize seeds were then sown in each pot, and two seedlings were left after emergence. Plants grew in a controlled environment glasshouse with a photoperiod of $14 \mathrm{~h}$ at a light intensity of $250 \mu \mathrm{mol} \mathrm{m} \mathrm{m}^{-2} \mathrm{~s}^{-1}$ provided by supplementary illumination. The temperature was $25^{\circ} \mathrm{C}$ at daytime and $18^{\circ} \mathrm{C}$ at night. Deionized water was added as required to maintain moisture content at about $50 \%$ of water holding capacity by regular weighing.

After growth for 8 weeks, shoots and roots were harvested separately. Root fragments were collected by sieving the soil and adding them to the root samples. Soils were sampled from each pot after mixed thoroughly. Roots were first carefully washed with tap water to remove any adhering soil particles. Then roots and shoots were rinsed thoroughly with deionized water, blotted dry, and weighed. Mycorrhizal colonization of roots was determined by the grid line intersect method (Giovannetti and Mosse 1980). The remaining plant and soils samples were then freezedried, ground, weighted, and stored at $4^{\circ} \mathrm{C}$. The fresh to dry root ratio was used to estimate the total dry mass of roots.

\section{Chemical analysis of $\mathrm{Hg}$}

Subsamples of $0.1 \mathrm{~g}$ dry plant materials were added with $3 \mathrm{~mL} \mathrm{HNO}_{3}$ in closed Teflon vessels and kept overnight and then were added with $3 \mathrm{~mL} \mathrm{H}_{2} \mathrm{O}_{2}$ and heated at $120^{\circ} \mathrm{C}$ for $2 \mathrm{~h}$. Soil samples $(0.1 \mathrm{~g})$ were digested with $3 \mathrm{~mL}$ 
$\mathrm{HNO}_{3}$ and $1 \mathrm{~mL} \mathrm{HClO}_{4}$ in closed Teflon vessels which were heated at $180^{\circ} \mathrm{C}$ for $4 \mathrm{~h}$ after kept overnight. Reagent blank and certified reference materials of NBS 1572 (citrus leaves) and NIST SRM 2709 (soil) were included to verify the accuracy and precision of the digestion procedure and subsequent analysis. The recovery rates were within $95 \pm$ $10 \%$. Available $\mathrm{Hg}$ in soil was extracted with $1 \mathrm{~mol} \mathrm{~L}^{-1}$ $\mathrm{CaCl}_{2}$ at $\mathrm{pH} 7.0$ for $1 \mathrm{~h}$ at room temperature. The solutions were then centrifuged at 2,000 rpm for $10 \mathrm{~min}$ and filtered. Mercury concentration was determined by a hydride generation atomic fluorescence spectrometer (HG-AFS; AF-610A, Beijing RuiLi Instrumental Company, Beijing, China).

\section{Sorption of $\mathrm{Hg}$ on soil}

Sorption of $\mathrm{Hg}$ on soil was carried out in batch equilibration experiment using the $\mathrm{Hg}$-free control soils collected after maize growth for both the mycorrhizal and nonmycorrhizal treatments. Experiments were carried out in triplicate by using the soils collected from separate pots without further mixing. Portions of $0.5 \mathrm{~g}$ soil were transferred into $50-\mathrm{mL}$ polypropylene centrifuge tubes, and $25 \mathrm{~mL}$ of $0.01 \mathrm{~mol} \mathrm{~L}^{-1} \mathrm{CaCl}_{2}$ (pH7.8) solution containing different levels of $\mathrm{Hg}(0,0.01,0.02,0.05$, $0.10,0.20,0.50,1.00,2.00$, and $5.00 \mathrm{mg} \mathrm{kg}^{-1}$, used as $\mathrm{HgCl}_{2}$ ) was added to each tube. The tubes were shaken at $100 \mathrm{rpm}$ for $5.0 \mathrm{~h}$ at $20^{\circ} \mathrm{C}$. Then the suspensions were centrifuged at 2,000 rpm for $10 \mathrm{~min}$ followed by filtering. $\mathrm{Hg}$ concentration in the filtered solutions was determined by HG-AFS after appropriate dilution.

Kinetic uptake of $\mathrm{Hg}$ by roots

Mycorrhizal and nonmycorrhizal roots were prepared separately for the test of $\mathrm{Hg}$ uptake. Methods for inoculation and plant growth in noncontaminated soil were the same as described above. Experimental design for $\mathrm{Hg}$ uptake by roots was adopted from the method of Esteban et al. (2008). In brief, roots were excised at the basal node after carefully washed by soaking in water to remove soil particles. Triplicate root samples $(0.2-0.5 \mathrm{~g}$ fresh weight) were incubated in aerated test solution (containing $5.0 \mathrm{mM}$ morpholinoethanesulfonic acid and $0.5 \mathrm{mM} \mathrm{Ca}\left(\mathrm{NO}_{3}\right)_{2}$, adjusted to pH5.0 using $\mathrm{KOH}$ ) for $30 \mathrm{~min}$ at $20^{\circ} \mathrm{C}$ in a water base. Then the roots were incubated in aerated test solutions with different concentrations of $\mathrm{Hg}\left(0,0.2,0.5,1.0\right.$, and $2.0 \mathrm{mg} \mathrm{L}^{-1}$, used as $\mathrm{HgCl}_{2}$ ) for $20 \mathrm{~min}$. After incubation in the test solution, the roots were then rinsed in ice-cold phosphate solution containing $1 \mathrm{mM} \mathrm{K}_{2} \mathrm{HPO}_{4}$ to remove any adsorbed $\mathrm{Hg}$ from the root-free space and stop further root activity. The roots were freeze-dried and weighed. Digestion and analysis of the samples were conducted following the methods described above.

\section{Determination of $\mathrm{Hg}$ evaporation}

Evaporation of $\mathrm{Hg}$ from soil was monitored separately using soil spiked with $4.0 \mathrm{mg} \mathrm{kg}^{-1} \mathrm{Hg}$. Triplicate pots were prepared for mycorrhizal and nonmycorrhizal treatments with and without plant growth. After 1 month of plant growth, each pot was enclosed within an acrylic chamber (10.5 L volume). Air Hg was monitored by the method of Moreno et al. (2005) with some modifications. In brief, a continuous air flow was supplied using a small air pump, and the flow rate was held constant at

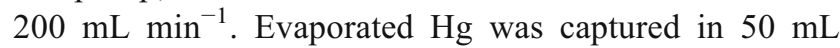
acid trap solution containing $5 \% \mathrm{KMnO}_{4}$ dissolved in 1 mol L ${ }^{-1} \mathrm{H}_{2} \mathrm{SO}_{4}$ for a 1-day period. The trap solution was then neutralized by the addition of oxammonium hydrochloride solution $\left(100 \mathrm{gL}^{-1}\right)$ and subjected to analysis of $\mathrm{Hg}$ with $\mathrm{HG}-\mathrm{AFS}$.

\section{Statistical analyses}

All data are presented as the average of triplicates. Significant $(P \leq 0.05)$ treatment effects were determined by one-way analysis of variance using SPSS 11.0 software.

\section{Results}

Colonization rate, biomass, and concentration of $\mathrm{Hg}$ in maize

Roots of inoculated plants were extensively colonized by G. mosseae, while noninoculated controls remained nonmycorrhizal. The percentages of root length colonized were $77 \%, 78 \%, 74 \%$, and $75 \%$ at $\mathrm{Hg}$ application rates of $0,1.0$, 2.0 , and $4.0 \mathrm{mg} \mathrm{kg}^{-1}$, respectively. Addition of $\mathrm{Hg}$ in soil did not significantly influence root colonization rate.

Table 1 displays the maize biomass and concentration of $\mathrm{Hg}$ in maize roots and shoots. Neither $\mathrm{Hg}$ addition nor mycorrhizal treatment significantly influenced the biomass. The accumulation of $\mathrm{Hg}$ in roots increased consistently with increasing $\mathrm{Hg}$ concentration in soil irrespective of inoculation treatment. Shoot $\mathrm{Hg}$ concentration was in the range of $0.030-0.045 \mathrm{mg} \mathrm{kg}^{-1}$, which was much lower than root concentration and did not change obviously with increasing soil $\mathrm{Hg}$ concentration. Mycorrhizal inoculation significantly reduced $\mathrm{Hg}$ concentration in maize roots when $\mathrm{Hg}$ was applied at the rates of 2.0 and $4.0 \mathrm{mg} \mathrm{kg}^{-1}$, while the concentration of $\mathrm{Hg}$ in shoots was not significantly different between nonmycorrhizal and mycorrhizal plants. 
Table 1 Dry biomass and concentrations of $\mathrm{Hg}$ in maize roots and shoots for nonmycorrhizal and mycorrhizal treatments (mean $\pm \mathrm{SE}, n=3$ ) $M$ mycorrhizal treatment

${ }^{a}$ Means difference at significant level of $5 \%$ between inoculation treatments in each $\mathrm{Hg}$ addition level

\begin{tabular}{|c|c|c|c|c|c|}
\hline \multirow[t]{2}{*}{$\mathrm{Hg}$ addition $\left(\mathrm{mgkg}^{-1}\right)$} & \multirow[t]{2}{*}{ Inoculation treatment } & \multicolumn{2}{|c|}{ Dry biomass $\left(\operatorname{gpot}^{-1}\right)$} & \multicolumn{2}{|c|}{$\mathrm{Hg}$ concentration $\left(\mathrm{mgkg}^{-1}\right)$} \\
\hline & & Root & Shoot & Root & Shoot \\
\hline \multirow[t]{2}{*}{0} & NM & $6.4 \pm 0.3$ & $11.2 \pm 0.1$ & $0.05 \pm 0.01$ & $0.035 \pm 0.006$ \\
\hline & M & $6.0 \pm 0.1$ & $11.9 \pm 0.4$ & $0.04 \pm 0.01$ & $0.032 \pm 0.007$ \\
\hline \multirow[t]{2}{*}{1.0} & NM & $6.5 \pm 0.3$ & $10.7 \pm 0.5$ & $0.26 \pm 0.06$ & $0.037 \pm 0.004$ \\
\hline & M & $7.0 \pm 0.1$ & $10.5 \pm 0.1$ & $0.30 \pm 0.04$ & $0.030 \pm 0.007$ \\
\hline \multirow[t]{2}{*}{2.0} & NM & $6.0 \pm 0.4$ & $10.9 \pm 0.1$ & $1.05 \pm 0.10^{\mathrm{a}}$ & $0.035 \pm 0.003$ \\
\hline & M & $6.2 \pm 0.6$ & $10.9 \pm 0.4$ & $0.80 \pm 0.09$ & $0.040 \pm 0.016$ \\
\hline \multirow[t]{2}{*}{4.0} & NM & $6.9 \pm 0.5$ & $10.9 \pm 0.5$ & $1.83 \pm 0.08^{\mathrm{a}}$ & $0.040 \pm 0.012$ \\
\hline & M & $6.7 \pm 0.2$ & $11.3 \pm 0.3$ & $1.33 \pm 0.14$ & $0.045 \pm 0.011$ \\
\hline
\end{tabular}

Concentrations of $\mathrm{Hg}$ in soil and $\mathrm{Hg}$ evaporated from soil

Concentrations of the total and extractable $\mathrm{Hg}$ in soil after plant harvest are given in Table 2. The residual $\mathrm{Hg}$ concentrations in soils decreased by $16.5-34.5 \%$ compared with their initial concentrations. Mycorrhizal treatment led to a lower $\mathrm{Hg}$ concentration in soil than the nonmycorrhizal treatment. $\mathrm{CaCl}_{2}$-extractable $\mathrm{Hg}$ has been shown to correlate with its accumulation in plants and is considered to represent the bioavailable fraction of $\mathrm{Hg}$ in soil (Panda et al. 1992; Zagury et al. 2006). The $\mathrm{CaCl}_{2}$-extractable $\mathrm{Hg}$ concentration in soil was very low, ranged from $0.12 \%$ to $0.31 \%$ of the total $\mathrm{Hg}$ in soil. Mycorrhizal inoculation significantly reduced the extractable $\mathrm{Hg}$ concentration as well as the ratio of extractable to the total $\mathrm{Hg}$ in soil when $\mathrm{Hg}$ was added at the levels of 2.0 and $4.0 \mathrm{mg} \mathrm{kg}^{-1}$.

Evaporated $\mathrm{Hg}$ detected for each treatment in a 1-day period was plotted in Fig. 1. Pots with plant growth had higher $\mathrm{Hg}$ evaporation $\left(4.8 \pm 0.9 \mu \mathrm{g} \mathrm{pot}^{-1} \mathrm{day}^{-1}\right)$ than those of plant-free control $\left(3.1 \pm 0.6 \mu \mathrm{g} \mathrm{pot}^{-1} \mathrm{day}^{-1}\right)$. Mycorrhizal inoculation significantly enhanced $\mathrm{Hg}$ evaporation from soil.

Table 2 The residual and extractable Hg concentrations in the soils and the calculated proportion of evaporated Hg after plant cultivation (mean \pm SE, $n=3)$

\begin{tabular}{|c|c|c|c|c|c|c|}
\hline \multirow{2}{*}{$\begin{array}{l}\mathrm{Hg} \text { addition } \\
\left(\mathrm{mgkg}^{-1}\right)\end{array}$} & \multirow{2}{*}{$\begin{array}{l}\text { Plant } \\
\text { treatment }\end{array}$} & \multirow{2}{*}{$\begin{array}{l}\text { Inoculation } \\
\text { treatment }\end{array}$} & \multirow{2}{*}{$\begin{array}{l}\text { Residual concentration } \\
\left(\mathrm{mgkg}^{-1}\right)\end{array}$} & \multicolumn{2}{|c|}{ Extractable concentration } & \multirow{2}{*}{$\begin{array}{l}\text { Calculated proportion of } \\
\text { evaporated } \mathrm{Hg}(\%)\end{array}$} \\
\hline & & & & $\mu \mathrm{gkg}^{-1}$ & $\%$ & \\
\hline \multirow[t]{4}{*}{0} & \multirow[t]{2}{*}{ No plant } & NM & $0.03 \pm 0.01$ & $0.07 \pm 0.02$ & $0.20 \pm 0.03$ & $16.7 \pm 14.4$ \\
\hline & & M & $0.03 \pm 0.01$ & $0.07 \pm 0.02$ & $0.22 \pm 0.06$ & $16.2 \pm 12.4$ \\
\hline & \multirow[t]{2}{*}{ Plant } & NM & $0.03 \pm 0.01$ & $0.05 \pm 0.03$ & $0.12 \pm 0.04$ & $18.0 \pm 15.0$ \\
\hline & & M & $0.03 \pm 0.01$ & $0.05 \pm 0.04$ & $0.13 \pm 0.05$ & $22.6 \pm 20.3$ \\
\hline \multirow[t]{4}{*}{1} & \multirow[t]{2}{*}{ No plant } & NM & $0.90 \pm 0.03$ & $2.94 \pm 0.62$ & $0.33 \pm 0.08$ & $13.8 \pm 2.9$ \\
\hline & & M & $0.88 \pm 0.06$ & $2.62 \pm 0.37$ & $0.30 \pm 0.06$ & $15.4 \pm 5.4$ \\
\hline & \multirow[t]{2}{*}{ Plant } & NM & $0.79 \pm 0.07$ & $1.21 \pm 0.32$ & $0.15 \pm 0.03$ & $21.0 \pm 7.3$ \\
\hline & & M & $0.73 \pm 0.08$ & $1.16 \pm 0.3$ & $0.16 \pm 0.03$ & $26.1 \pm 7.6$ \\
\hline \multirow[t]{4}{*}{2} & \multirow[t]{2}{*}{ No plant } & NM & $1.73 \pm 0.15$ & $9.74 \pm 0.93$ & $0.57 \pm 0.10$ & $15.0 \pm 7.5$ \\
\hline & & M & $1.70 \pm 0.10$ & $10.00 \pm 1.00$ & $0.59 \pm 0.09$ & $16.7 \pm 4.9$ \\
\hline & \multirow[t]{2}{*}{ Plant } & NM & $1.51 \pm 0.11^{\mathrm{a}}$ & $3.36 \pm 0.74^{\mathrm{a}}$ & $0.31 \pm 0.05^{\mathrm{a}}$ & $24.0 \pm 5.6^{\mathrm{a}}$ \\
\hline & & M & $1.31 \pm 0.06$ & $1.76 \pm 0.45$ & $0.19 \pm 0.05$ & $33.8 \pm 3.2$ \\
\hline \multirow[t]{4}{*}{4} & \multirow[t]{2}{*}{ No plant } & NM & $3.60 \pm 0.17$ & $23.33 \pm 2.89$ & $0.65 \pm 0.10$ & $10.9 \pm 4.3$ \\
\hline & & M & $3.55 \pm 0.17$ & $21.67 \pm 1.53$ & $0.61 \pm 0.03$ & $12.1 \pm 4.3$ \\
\hline & \multirow[t]{2}{*}{ Plant } & $\mathrm{NM}$ & $3.34 \pm 0.16^{\mathrm{a}}$ & $4.49 \pm 1.18^{\mathrm{a}}$ & $0.27 \pm 0.06^{\mathrm{a}}$ & $15.8 \pm 4.1^{\mathrm{a}}$ \\
\hline & & $\mathrm{M}$ & $2.90 \pm 0.14$ & $2.12 \pm 0.18$ & $0.15 \pm 0.01$ & $27.0 \pm 3.5$ \\
\hline
\end{tabular}

$N M$ nonmycorrhizal treatment, $M$ mycorrhizal treatment

${ }^{a}$ Means difference at significant level of $5 \%$ between inoculation treatments in each $\mathrm{Hg}$ addition level

${ }^{\mathrm{b}}$ Ratio of the extractable $\mathrm{Hg}$ to the total $\mathrm{Hg}$ in soil after plant harvest 


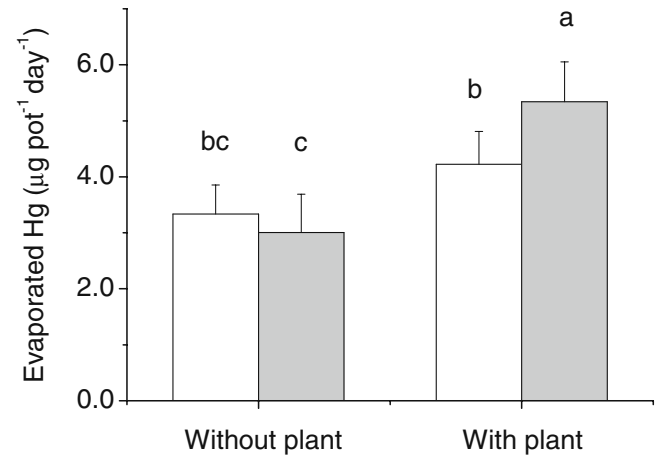

Fig. 1 Amount of evaporated $\mathrm{Hg}$ from soil for the treatments with and without plant growth, with (closed bar) and without (open bar) mycorrhizal inoculation. Soil was spiked with $\mathrm{Hg}$ at $4.0 \mathrm{mg} \mathrm{kg}^{-1}$. Data represent mean $\pm \mathrm{SE}, n=3$. Means with the same letter are not significantly different at the $5 \%$ level

\section{Sorption of $\mathrm{Hg}$ on soil}

In order to determine the influence of mycorrhizal inoculation on $\mathrm{Hg}$ immobilization in soil, sorption of $\mathrm{Hg}$ was investigated using the soils collected after plant harvest with or without mycorrhizal treatment, and the results are given in Fig. 2. The soil with previous mycorrhizal treatment showed a higher sorption capacity for $\mathrm{Hg}$ than did the soil without mycorrhizal treatment $(P<0.01)$. Mercury sorption on soil can be well described by Langmuir $\left(C / X=C / X_{\mathrm{m}}+1 /\left(X_{\mathrm{m}} \times K\right)\right)$ sorption model (Table 3). The correlation coefficients $\left(R^{2}\right)$ were 0.9997 and 0.9977 for mycorrhizal and nonmycorrhizal treatments, respectively. The monolayer maximum sorption $\left(X_{\mathrm{m}}\right)$ obtained from Langmuir equation is frequently used to compare the potential sorption capacity of different soils or soil components. A higher $X_{\mathrm{m}}$ value $\left(257.3 \mathrm{mg} \mathrm{kg}^{-1}\right)$ was obtained for mycorrhizal treatment compared with the nonmycorrhizal treatment $\left(235.8 \mathrm{mg} \mathrm{kg}{ }^{-1}\right)$. The physical meaning of $K$ is usually related to the binding energy of an

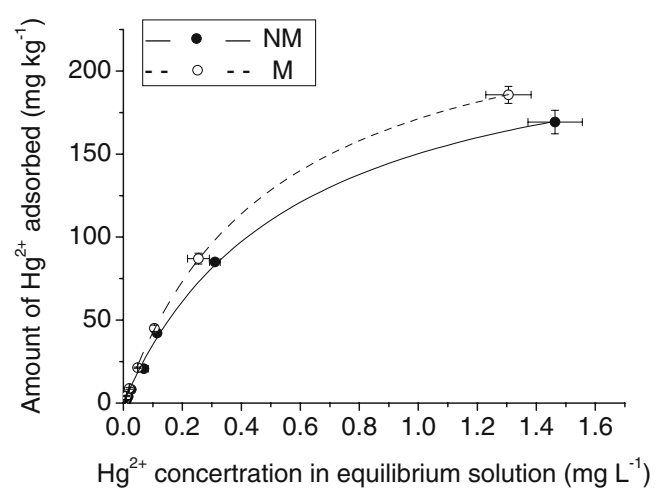

Fig. 2 Isotherms of $\mathrm{Hg}$ sorption on soils after cultivation of mycorrhizal $(M)$ and nonmycorrhizal $(N M)$ maize plants. Means and standard errors $(n=3)$ on a dry matter basis are presented
Table 3 Isothermal characteristics of Langmuir equation for $\mathrm{Hg}$ sorption on soils for nonmycorrhizal and mycorrhizal treatments

\begin{tabular}{llll}
\hline Inoculation treatment & $X_{\mathrm{m}}\left(\mathrm{mgkg}^{-1}\right)$ & $K$ & $R^{2}$ \\
\hline $\mathrm{NM}$ & $235.8 \pm 7.9$ & $1.75 \pm 0.14$ & 0.9977 \\
$\mathrm{M}$ & $257.3 \pm 2.8$ & $1.99 \pm 0.05$ & 0.9997 \\
\hline
\end{tabular}

$N M$ nonmycorrhizal treatment, $M$ mycorrhizal treatment

ion adsorbed. The greater the $K$ value is, the more tightly the adsorbed ion is bonded. The $K$ values were 1.99 and 1.75 for mycorrhizal and nonmycorrhizal treatments, respectively.

Kinetic uptake of $\mathrm{Hg}$

Figure 3 shows the kinetic uptake of $\mathrm{Hg}$ by mycorrhizal and nonmycorrhizal roots. The uptake of $\mathrm{Hg}$ by roots showed a hyperbolic increase with increasing $\mathrm{Hg}$ concentration in the test solution. The mycorrhizal roots took up significantly less $\mathrm{Hg}$ than the nonmycorrhizal roots. The uptake kinetics can be adequately described by the Michaelis-Menten function (Table 4). There was no significant difference in $V_{\max }$ values (the maximum velocity) between the mycorrhizal and nonmycorrhizal treatments, while mycorrhizal inoculation obviously increased the $K_{\mathrm{m}}$ values (Michaelis-Menten constant, which is the substrate concentration needed to achieve a halfmaximum velocity of uptake).

\section{Discussion}

All interactions of $\mathrm{Hg}$ with soil, roots, and mycelium influence its uptake by plants. Therefore, a detailed interpretation of each individual effect is difficult. Both

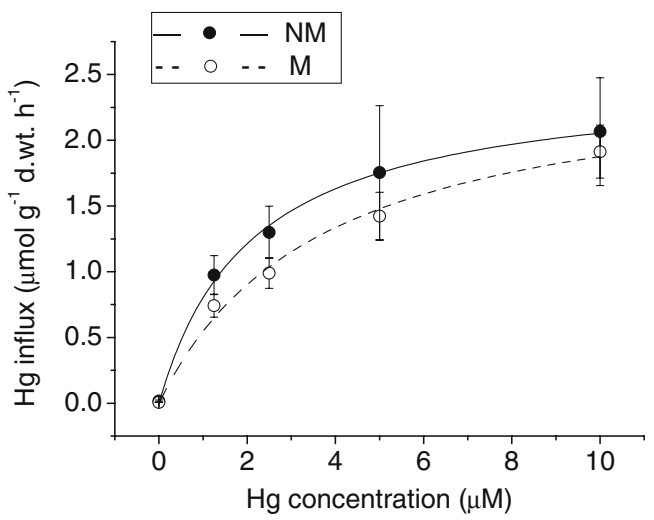

Fig. 3 Concentration-dependent kinetics for $\mathrm{Hg}$ uptake by roots of mycorrhizal $(M)$ and nonmycorrhizal $(N M)$ maize. Means and standard errors $(n=3)$ on a dry matter basis are presented 
Table 4 Kinetic parameters for $\mathrm{Hg}$ influx into maize roots for nonmycorrhizal and mycorrhizal treatments

\begin{tabular}{llll}
\hline $\begin{array}{l}\text { Inoculation } \\
\text { treatment }\end{array}$ & $\begin{array}{l}V_{\max }\left(\mu \operatorname{molg}{ }^{-1}\right. \\
\left.\text { d.wt. }{ }^{-1}\right)\end{array}$ & $K_{\mathrm{m}}(\mu \mathrm{M})$ & $R^{2}$ \\
\hline $\mathrm{NM}$ & $2.48 \pm 0.58$ & $2.09 \pm 0.59$ & 0.9287 \\
$\mathrm{M}$ & $2.58 \pm 0.39$ & $3.68 \pm 0.67$ & 0.8832 \\
\hline
\end{tabular}

$N M$ nonmycorrhizal treatment, $M$ mycorrhizal treatment

positive and negative effects of mycorrhizal inoculation on metal accumulation have been observed in previous works (Chen et al. 2005; Ahmed et al. 2006). Mercury concentration was significantly lower in mycorrhizal maize roots than in nonmycorrhizal roots when $\mathrm{Hg}$ was applied at the rates of 2.0 and $4.0 \mathrm{mg} \mathrm{kg}^{-1}$, which could be attributed to the decrease of bioavailable $\mathrm{Hg}$ in soil as the result of $\mathrm{AM}$ inoculation. Plant uptake should remove a part of bioavailable $\mathrm{Hg}$ in soil, and the removal fraction should be higher for nonmycorrhizal treatment because $\mathrm{Hg}$ accumulation was higher in nonmycorrhizal maize. Nevertheless, the bioavailable $\mathrm{Hg}$ in soil extracted by $\mathrm{CaCl}_{2}$ after maize harvest was lower for mycorrhizal treatment than nonmycorrhizal treatment. Bioavailability of an element in soil is highly controlled by its interactions with soil matrixes. The lower extractable $\mathrm{Hg}$ in soil for mycorrhizal treatment suggested a stronger interaction of $\mathrm{Hg}$ with soil compared with the nonmycorrhizal treatment. A batch equilibration experiment was further conducted to exam the influence of mycorrhizal inoculation on the sorption of $\mathrm{Hg}$ on soil. The results indicated that mycorrhizal inoculation remarkably enhanced $\mathrm{Hg}$ sorption on soil. Several aspects could be expected to influence $\mathrm{Hg}$ sorption on soil. AM fungi can influence soil $\mathrm{pH}$ value and soil aggregation ( $\mathrm{Li}$ and Christie 2001; Solaiman and Abbott 2004) which are among the key factors influencing $\mathrm{Hg}$ sorption/desorption on soil. In addition, the abundant extraradical mycelium produced by AM fungi has a high cation exchange capacity (up to several hundred centimoles per kilogram) and has been confirmed to have high sorption capacities for $\mathrm{Cu}, \mathrm{Zn}$, and Cd (Joner et al. 2000; Chen et al. 2001; GonzálezChávez et al. 2002). Mycorrhizal fungi also secrete a gooey protein known as glomalin, which can immobilize heavy metals such as $\mathrm{Cu}, \mathrm{Cd}, \mathrm{Zn}, \mathrm{Pb}$, and $\mathrm{Mn}$ in soils and decrease their availability to soil microorganisms and plants (González-Chávez et al. 2004). It can be speculated that mycelium and glomalin might also have a strong sequestering ability toward $\mathrm{Hg}$. Enhanced immobilization of soil $\mathrm{Hg}$ by mycorrhizal inoculation is important to reduce its potential risks to transfer into the food chain and contaminate surface and ground waters.

Kinetic uptake of $\mathrm{Hg}$ by roots was studied and the results showed that mycorrhizal roots had a lower uptake of $\mathrm{Hg}$ compared with nonmycorrhizal roots. $K_{\mathrm{m}}$ in MichaelisMenten equation approximately describes the affinity of the substrate for uptake carriers. The higher $K_{\mathrm{m}}$ value for the mycorrhizal treatment indicated that the uptake carriers of mycorrhizal roots had a lower affinity toward $\mathrm{Hg}$ ion compared with that of nonmycorrhizal roots. Furthermore, hyphae of AM fungi, which contain free amino, hydroxyl, carboxyl, and other groups (Smith and Read 1997), could enter inside plant cells and change cell wall components, possibly enhancing the binding of $\mathrm{Hg}$ on hyphae and root surface. As a result, $\mathrm{Hg}$ translocation into roots could be inhibited.

The primary sources of $\mathrm{Hg}$ in shoots include translocation of soil $\mathrm{Hg}$ through roots and foliar uptake from the air (Ericksen and Gustin 2004). Various studies have indicated that only a very small amount of $\mathrm{Hg}$ is translocated to plant shoot after root uptake and $\mathrm{Hg}$ in shoots mainly comes from the uptake of air Hg (Ericksen and Gustin 2004; Greger et al. 2005; Fay and Gustin 2007). In the present study, shoot $\mathrm{Hg}$ concentration was found much lower than that in roots and did not correlate with $\mathrm{Hg}$ concentration in either maize roots or soil. Furthermore, there was no significant difference in shoot $\mathrm{Hg}$ concentration among the treatments including $\mathrm{Hg}$ addition in soil and mycorrhizal inoculation. These evidences support the view that contribution of root uptake to shoot accumulation of $\mathrm{Hg}$ is very limited.

Supposing maize shoots took up $\mathrm{Hg}$ from the air, there should be $\mathrm{Hg}$ evaporation from soil as the source of air $\mathrm{Hg}$. Furthermore, we noticed that the total $\mathrm{Hg}$ content in soil with maize growth was lower for mycorrhizal treatment than for nonmycorrhizal treatment, although mycorrhizal maize accumulated less $\mathrm{Hg}$ than nonmycorrhizal maize. Leaching of $\mathrm{Hg}$ from soil was avoided because there was no drain hole in the bottom of the pots. Therefore, $\mathrm{Hg}$ losses from soil might also contribute to its evaporation from soil to the air. Based on this hypothesis, the proportion of $\mathrm{Hg}$ evaporated $\left(Q_{\mathrm{v}}\right)$ was calculated by the following equation:

$Q_{\mathrm{v}}(\%)=\frac{Q_{0}-Q_{\mathrm{s}}-Q_{\mathrm{p}}}{Q_{0}} \times 100 \%$

where, $Q_{0}$ (milligrams per pot), $Q_{\mathrm{s}}$ (milligrams per pot), and $Q_{\mathrm{p}}$ (milligrams per pot) are the amounts of $\mathrm{Hg}$ initially added to soil, retained in the soil after plant harvest, and accumulated in plants, respectively. Based on the evidence of extremely low $\mathrm{Hg}$ content in maize shoots (less than $0.07 \%$ of $\mathrm{Hg}$ added in soils), the contribution of leaf-to-air exchange of $\mathrm{Hg}$ (evaporation and/or sorption of $\mathrm{Hg}$ vapor) was ignored to the mass balance of $\mathrm{Hg}$ in soil-plant system. Mass balance calculation indicates that mycorrhizal treatment led to a markedly higher proportion of evaporated $\mathrm{Hg}$ than nonmycorrhizal treatment. A chamber study was further conducted to monitor the evaporated $\mathrm{Hg}$. Evaporation of $\mathrm{Hg}$ from soil has been evidenced (Schlüter 2000). In this study, 
it was observed that plants growth enhanced $\mathrm{Hg}$ evaporation from soil and mycorrhizal inoculation further promoted the enhancement. We speculate that the increase of Hg evaporation would contribute to the enhanced soil microbial activity since plant roots particularly inoculated roots can greatly increase soil microbial activity (Wu et al. 2008).

Mercury usually evaporates from soil to the air as the forms of organic $\mathrm{Hg}$ and $\mathrm{Hg}(0)$. A biological transformation of $\mathrm{Hg}(\mathrm{II})$ to organic $\mathrm{Hg}$ and/or $\mathrm{Hg}(0)$ can occur in the uppermost soil layer, which is the rate-limiting process of $\mathrm{Hg}$ evaporation from soil (Schlüter 2000). In this experiment, soils were extracted and analyzed for $\mathrm{Hg}$ speciation by high-performance liquid chromatography-inductively coupled argon plasma mass spectrometry following the method described by Cattani et al. (2008). Only Hg(II) was present in the soil, and neither methyl-Hg nor ethyl-Hg was detected (data not shown). It suggests that no transformation of $\mathrm{Hg}$ (II) to organic species occurred in soil. It has been expected that topsoil with high organic matter and high microbial activity is the major source of $\mathrm{Hg}$ reduction and evaporation (Schlüter 2000). Mycorrhizal fungi can secrete organic materials and regulate root exudation into soil (Jones et al. 2004), leading to a change in the quantity and composition of soil organic matter. Furthermore, mycorrhizal inoculation has been identified to result in an increase in soil microbial activity particularly in the rhizosphere soil (Wu et al. 2008; Huang et al. 2009), which can benefit the reduction of $\mathrm{Hg}$ (II) and $\mathrm{Hg}$ evaporation. Emission of $\mathrm{Hg}$ from soil is a significant source of $\mathrm{Hg}$ in the atmosphere, and comprehensive investigations are necessary to elucidate the role of mycorrhizal fungi in $\mathrm{Hg}$ circulation in biological environment.

To our knowledge, the present study is the first report about the effects of mycorrhizal inoculation on $\mathrm{Hg}$ behavior in soil-plant system. AM inoculation reduced bioavailable fraction of $\mathrm{Hg}$ in soil and $\mathrm{Hg}$ uptake by roots, thus leading to a lower accumulation in maize. In addition, evaporation of $\mathrm{Hg}$ from soil to atmosphere was promoted by mycorrhizal treatment. The findings of this study indicate that AM fungi play an important role in the transport and fate of $\mathrm{Hg}$ in the soil-plant system.

Acknowledgment This work was funded by the Knowledge Innovation Program of the Chinese Academy of Sciences (Project Kzcx-1-YW-06-03), the National Natural Science Foundation of China (Project 40730740), and the Chinese High Technology Research and Development Programme (Project 2006AA06Z349).

\section{References}

Ahmed FRS, Killham K, Alexander I (2006) Influences of arbuscular mycorrhizal fungus Glomus mosseae on growth and nutrition of lentil irrigated with arsenic contaminated water. Plant Soil 258:33-41

Cattani I, Spalla S, Beone GM, Del Re AAM, Boccelli R, Trevisan M (2008) Characterization of mercury species in soils by HPLCICP-MS and measurement of fraction removed by diffusive gradient in thin films. Talanta 74:1520-1526

Chen BD, Christie P, Li XL (2001) A modified glass bead compartment cultivation system for studies on nutrient and trace metal uptake by arbuscular mycorrhiza. Chemosphere 42:185-192

Chen X, Wu C, Tang J, Hu S (2005) Arbuscular mycorrhizae enhance metal lead uptake and growth of host plants under a sand culture experiment. Chemosphere 60:665-671

Ericksen JA, Gustin MS (2004) Foliar exchange of mercury as a function of soil and air mercury concentrations. Sci Total Environ 324:271-279

Esteban E, Moreno E, Peňalosa J, Cabrero JI, Millán R, Zornoza P (2008) Short and long-term uptake of $\mathrm{Hg}$ in white lupin plants: kinetics and stress indicators. Environ Exp Bot 62:316-322

Fay L, Gustin M (2007) Assessing the influence of different atmospheric and soil mercury concentrations on foliar mercury concentrations in a controlled environment. Water Air Soil Poll $181: 373-384$

Gabriel MC, Williamson DG (2004) Principal biogeochemical factors affecting the speciation and transport of mercury through the terrestrial environment. Environ Geochem Health 26:421-434

Giovannetti M, Mosse B (1980) An evaluation of techniques for measuring vesicular arbuscular mycorrhizal infection in roots. New Phytol 84:489-500

Gnamuš A, Byrne AR, Horvat M (2000) Mercury in the soil-plantdeer-predator food chain of a temperate forest in Slovenia. Environ Sci Tech 34:3337-3345

González-Chávez C, D'Haen J, Vangronsveld J, Dodd JC (2002) Copper sorption and accumulation by the extraradical mycelium of different Glomus spp. (arbuscular mycorrhizal fungi) isolated from the same polluted soil. Plant Soil 240:287-297

González-Chávez MC, Carrillo-González R, Wright SF, Nichols KA (2004) The role of glomalin, a protein produced by arbuscular mycorrhizal fungi, in sequestering potentially toxic elements. Environ Pollut 130:317-323

Greger M, Wang YD, Neuschütz C (2005) Absence of $\mathrm{Hg}$ transpiration by shoot after $\mathrm{Hg}$ uptake by roots of six terrestrial plant species. Environ Pollut 134:201-208

Grigal DF (2003) Mercury sequestration in forests and peatlands: a review. J Environ Qual 32:393-405

Han FXX, Banin A, Su Y, Monts DL, Plodinec MJ, Kingery WL, Triplett GE (2002) Industrial age anthropogenic inputs of heavy metals into the pedosphere. Naturwissenschaften 89:497-504

Huang HL, Zhang SZ, Wu NY, Luo L, Christie P (2009) Influence of Glomus etunicatum/Zea mays mycorrhiza on atrazine degradation, soil phosphatase and dehydrogenase activities, and soil microbial community structure. Soil Biol Biochem 41:726-734

Janoušková M, Pavlíková D, Vosátka M (2006) Potential contribution of arbuscular mycorrhiza to cadmium immobilisation in soil. Chemosphere 65:1959-1965

Joner EJ, Briones R, Leyval C (2000) Metal-binding capacity of arbuscular mycorrhizal mycelium. Plant Soil 226:227-234

Jones DL, Hodge A, Kuzyakov Y (2004) Plant and mycorrhizal regulation of rhizodeposition. New Phytol 163:459-480

Li XL, Christie P (2001) Changes in soil solution $\mathrm{Zn}$ and $\mathrm{pH}$ and uptake of $\mathrm{Zn}$ by arbuscular mycorrhizal red clover in $\mathrm{Zn}$ contaminated soil. Chemosphere 42:201-207

Marques APGC, Oliveira RS, Rangel AOSS, Castro PML (2006) Zinc accumulation in Solanum nigrum is enhanced by different arbuscular mycorrhizal fungi. Chemosphere 65:1256-1263

Millán R, Gamarra R, Schmid T, Sierra MJ, Quejido AJ, Sánchez DM, Cardona AI, Fernández A, Vera R (2006) Mercury content in 
vegetation and soils of the Almadén mining area (Spain). Sci Total Environ 368:79-87

Moreno FN, Anderson CWN, Stewart RB, Robinson BH (2005) Mercury volatilisation and phytoextraction from base-metal mine tailings. Environ Pollut 136:341-352

Panda KK, Lenka M, Panda BB (1992) Monitoring and assessment of mercury pollution in the vicinity of a chloralkali plant. 2 . Plant-availability, tissue-concentration and genotoxicity of mercury from agricultural soil contaminated with solid-waste assessed in Barley (Hordeum-vulgare L). Environ Pollut 76:3342

Porter WM (1979) The 'most probable number' method for enumerating infective propagules of vesicular mycorrhizal fungi in soil. Aust J Soil Res 17:515-519

Schlüter K (2000) Review: evaporation of mercury from soils. An integration and synthesis of current knowledge. Environ Geol 39:249-271

Schuster E (1991) The behavior of mercury in the soil with special emphasis on complexation and adsorption processes - a review of the literature. Water Air Soil Poll 56:667-680
Smith SE, Read DJ (1997) Mycorrhizal symbiosis. Academic, London Solaiman MZ, Abbott LK (2004) Functional diversity of arbuscular mycorrhizal fungi on root surfaces. In: Varma A, Abbott LK, Werner D, Hampp R (eds) Plant surface microbiology. Springer, Heidelberg, pp 340-341

Wu NY, Zhang SZ, Huang HL, Shan XQ, Christie P, Wang YS (2008) DDT uptake by arbuscular mycorrhizal alfalfa and depletion in soil as influenced by soil application of a non-ionic surfactant. Environ Pollut 151:569-575

Yin YJ, Allen HE, Huang CP, Sparks DL, Sanders PF (1997) Kinetics of mercury(II) adsorption and desorption on soil. Environ Sci Technol 31:496-503

Yu Y, Zhang SZ, Huang HL, Luo L, Wen B (2009) Arsenic accumulation and speciation in maize as affected by inoculation with arbuscular mycorrhizal fungus Glomus mosseae. J Agr Food Chem 57:3695-3701

Zagury GJ, Neculita CM, Bastien C, Deschĕnes L (2006) Mercury fractionation, bioavailability, and ecotoxicity in highly contaminated soils from chlor-alkali plants. Environ Toxicol Chem 25:1138-1147 